\title{
Analisis Efektivitas Dana Bantuan Operasional Sekolah (BOS) di Sekolah Menengah Kejuruan Negeri (SMKN) Kota Bandung
}

\author{
Nur Azizah Fauziyyah ${ }^{1}$, Heni Mulyani ${ }^{2}$, Imas Purnamasari ${ }^{3}$ \\ Program Studi Pendidikan Akuntansi, FPEB, Universitas Pendidikan Indonesia, Bandung, Indonesia ${ }^{1}$ \\ Program Studi Pendidikan Akuntansi, FPEB, Universitas Pendidikan Indonesia, Bandung, Indonesia ${ }^{2}$ \\ Program Studi Pendidikan Akuntansi, FPEB, Universitas Pendidikan Indonesia, Bandung, Indonesia ${ }^{3}$
}

\begin{abstract}
.
This research is motivated by indications of funds that should be funded by government funds, but still taken from the community. This study aims to look at the level of effectiveness of the School Operational Assistance Fund (BOS) in State Vocational High Schools (SMKN) in Bandung City. The approach in this study uses quantitative, and descriptive research methods. The population in this study were all State Vocational High Schools (SMKN) throughout Bandung as many as 15 State Vocational High Schools (SMKN). This research is census research. So that all populations will be sampled. Data collection techniques using documentation and interviews. Furthermore, the data analysis technique uses descriptive analysis. The results of the study state that the effectiveness of the school operational assistance fund (BOS) in state vocational high schools (SMKN) throughout Bandung is quite effective with a percentage of $88.67 \%$.
\end{abstract}

Keywords. effectiveness; school operational assistance fund

\begin{abstract}
Abstrak
Penelitian ini dilatarbelakangi oleh adanya indikasi dana yang seharusnya didanai oleh dana pemerintah, tetapi masih diambil dari masyarakat. Penelitian ini bertujuan untuk melihat tingkat Efektivitas Dana Bantuan Operasional Sekolah (BOS) di Sekolah Menengah Kejuruan Negeri (SMKN) Se-Kota Bandung. Pendekatan dalam penelitian ini menggunakan kuantitatif, dan metode penelitian deskriptif. Populasi dalam penelitian ini adalah seluruh Sekolah Menengah Kejuruan Negeri (SMKN) se-kota Bandung sebanyak 15 Sekolah Menengah Kejuruan Negeri (SMKN). Penelitian ini merupakan penelitian sensus. Sehingga semua populasi akan dijadikan sampel. Teknik pengumpulan data menggunakan dokumentasi dan wawancara. Selanjutnya teknik analisis data menggunakan analisis deskriptif. Hasil penelitian menyatakan bahwa tingkat efektivitas dana bantuan operasional sekolah (BOS) di sekolah menengah kejuruan negeri (SMKN) se-kota Bandung tergolong cukup efektif dengan persentase $88.67 \%$.
\end{abstract}

Kata Kunci. efektivitas; dana bantuan operasional sekolah

Corresponding author. Email. henimulyani@upi.edu, imaspurnamasari@upi.edu

How to cite this article. Fauziyyah, N. A., Mulyani, H., \& Purnamasari, I. (2018). Analisis Efektivitas Dana Bantuan Operasional Sekolah ( BOS ) di Indonesia atas tanggung jawab Pemerintah. Jurnal Pendidikan Akuntansi Dan Keuangan, 5(1), 21-28. Retrieved from http://ejournal.upi.edu/index.php/JPAK/article/view/15828

History of article. Received: Agustus 2017, Revision: November 2017, Published: Januari 2018

\section{Pendahuluan}

Pendidikan Nasional mempunyai visi dan misi dalam mewujudkan tujuan yang diamanatkan dalam Undang-Undang Dasar Negara Republik Indonesia Tahun 1945 yaitu mencerdaskan kehidupan bangsa. Visi pendidikan nasional yaitu terwujudnya sistem pendidikan sebagai pranata sosial yang kuat dan berwibawa untuk memberdayakan semua warga Negara Indonesia berkembang menjadi manusia yang berkualitas sehingga mampu dan proaktif menjawab tantangan zaman yang selalu berubah. Berdasarkan visi tersebut, maka misi Pendidikan Nasional salah satunya menyatakan bahwa Pendidikan Nasional mengupayakan perluasan dan pemerataan kesempatan memperoleh pendidikan yang bermutu bagi seluruh rakyat Indonesia.

Implementasi dari misi Pendidikan Nasional di atas tertuang dalam Undangundang No. 20 tahun 2003 pasal 5 ayat 1 menyatakan bahwa setiap warga Negara mempunyai hak yang sama untuk memperoleh pendidikan yang bermutu. Untuk memperoleh

21 | Jurnal Pendidikan Akuntansi dan Keuangan 
hak pendidikan yang sama yaitu dengan Pemerintah mengeluarkan kebijakan yaitu kebijakan Wajib Belajar.

Wajib Belajar menurut UU No. 20 Tahun 2003 Pasal 1 ayat 18 adalah program pendidikan minimal yang harus diikuti oleh warga Negara Indonesia atas tanggung jawab Pemerintah Pusat dan Pemerintah Daerah. Maksud dari tanggung jawab Pemerintah Pusat dan Pemerintah Daerah adalah sebagaimana diamanatkan dalam UU No. 20 tahun 2003 Pasal 34 ayat 2 tentang Wajib Belajar yaitu Pemerintah dan Pemerintah Daerah menjamin terselenggaranya Wajib Belajar minimal pada jenjang pendidikan dasar tanpa memungut biaya.

Program pemerintah dalam menunjang wajib belajar 12 tahun adalah dengan adanya kebijakan dana Bantuan Operasional Sekolah (BOS), dana tersebut digunakan untuk membiayai dana operasional non personalia. Sehingga dapat meringankan beban masyarakat terhadap pembiayaan pendidikan. Dana yang dialirkan pemerintah kepada Sekolah Menengah Kejuruan Negeri khususnya sebesar Rp. 1.400.000,-/siswa. Tetapi pada kenyataannya dana Bantuan Operasional Sekolah tersebut belum sepenuhnya meringankan beban masyarakat. Hal tersebut dapat dilihat dari tabel berikut:

Tabel 1. Rencana Pemasukan Dana Sekolah (dalam Ribuan Rupiah)

\begin{tabular}{clr}
\hline No & \multicolumn{1}{c}{ Rencana Pemasukan } & Jumlah Dana \\
\hline I & Dari Pemerintah & \\
& 1. BOS Pusat & $1,831,200$ \\
& 2. BOS Provinsi & 392,400 \\
& 3. BAWAKU & 520,500 \\
& Jumlah I & $\mathbf{2 , 7 4 4 , 1 0 0}$ \\
II & Iuran dari Orang Tua & \\
& Iuran Peserta Didik Baru & $1,813,500$ \\
& Iuran bulanan siswa kelas X & $1,088,100$ \\
& Iuran bulanan siswa kelas & 201,000 \\
& XI & \\
& Iuran bulanan siswa kelas & 633,600 \\
& XII & 282,240 \\
& Iuran Kunjungan Industri & 141,750 \\
& (Kelas X) & \\
& Iuran PKL Siswa (Kelas & 184,320 \\
& XI) & 46,080 \\
& Iuran UKK (Kelas XII) & $\mathbf{4 , 3 9 0 , 5 9 0}$ \\
& Iuran BKK (Kelas XII) & $\mathbf{7 , 1 3 4 , 6 9 0}$ \\
$\quad$ Jumlah II & \\
$\quad$ Jumlah Total & \\
\hline Sumber : Data diolah salah satu Sekolah Menengah \\
Kejuruan Negeri di Kota Bandung
\end{tabular}

\footnotetext{
22 | Jurnal Pendidikan Akuntansi dan Keuangan
DOI.10.17509/jpak.v6i1.15828 | http://ejournal.upi.edu/index.php/JPAK

22 | Jurnal Pendidikan Akuntansi dan Keuangan
DOI.10.17509/jpak.v6i1.15828 | http://ejournal.upi.edu/index.php/JPAK
}

Jika melihat data dalam tabel 1.1 menunjukan bahwa masih ada biaya yang harus dikeluarkan oleh masyarakat untuk Praktek Kerja Lapangan (PKL), Uji Kompetensi Kejuruan (UKK), dan Bursa kerja Khusus (BKK). Tujuan dari dana BOS sendiri adalah untuk meringankan beban masyarakat dengan memberikan bantun berupa dana untuk membiayai operasional non personalia sekolah, salah satunya yaitu untuk membiayai penyelenggaraan PKL, UKK, dan BKK. Tetapi, dapat dilihat dari tabel di atas bahwa masih ada biaya yang harus dikeluarkan oleh masyarakat yang seharusnya sudah dibiayai oleh pemerintah.

Dampak dari permasalah di atas yaitu sekolah lebih mengutamakan dana dari masyarakat, sehingga program yang dijalankannya pun lebih banyak mengeluarkan dana dari masyarakat, yang akibatnya beban masyarakat masih berat meskipun sudah ada bantuan dari pemerintah.

Undang-undang No 17 Tahun 2003 menyatakan bahwa prinsip pengelolaan keuangan Negara oleh pemerintah baik pusat maupun daerah harus dikelola secara tertib dan taat pada peraturan perundang-undangan efektif, efisien, ekonomis, transparan dan bertanggung jawab dengan memperhatikan rasa keadilan dan kepatuhan.

Menurut Rutter et. Al. (1979) dan Johnson (1993:167) menyatakan bahwa Keefektifan organisasi pendidikan terletak pada: (1) pentingnya jam pelajaran yang penuh tidak ada yang kosong, (2) kerjasama yang baik antar pengajar, (3) memperhatikan kondisi fasilitas fisik dan ketersediaan anggaran, (4) konsisten dalam memberikan ganjaran atau hukuman atas sikap siswa. Ketersediaan anggaran dan penggunaan anggaran pendidikan yang tepat sasaran, menggunakan prosedur perencanaan bottom up system menggambarkan bahwa manajemen anggaran dilakukan untuk memenuhi target dan sasaran yang ditetapkan. Strategi anggaran ini menjadi jaminan bahwa efektivitas anggaran yang di fokuskan pada aktivitas pembelajaran di sekolah yang dilaksanakan sesuai dengan yang di programkan.

Mulyono (2010:81) mengemukakan: Biaya merupakan suatu unsur yang menentukan dalam mekanisme penganggaran. Penentuan biaya akan mempengaruhi tingkat efisiensi dan efektivitas kegiatan dalam suatu organisasi 
yang akan mencapai suatu tujuan tertentu. Kegiatan yang dilaksanakan dengan biaya yang rendah dan hasilnya mempunyai kualitas yang baik dapat dikatakan kegiatan tersebut dilaksanakan secara efisien dan efektif.

Berdasarkan paparan di atas maka dapat disimpulkan bahwa efektivitas adalah suatu ukuran yang menyatakan bahwa seberapa jauh target atau tujuan yang telah tercapai, yang kemudian di tindak lanjuti dalam penggunaan anggaran yang tepat sasaran. Efektivitas disini lebih menekankan kepada kualitatif outcomes, dimana manajemen keuangan dapat dikatakan efektif memenuhi prinsip efektivitas kalau kegiatan yang dilakukan dapat mengatur keuangan untuk membiayai aktivitas atau kegiatan dalam rangka mencapai tujuan lembaga yang bersangkutan dengan outcomenya sesuai dengan rencana yang telah ditetapkan. Hal tersebut sejalan dengan yang dituangkan dalam Juknis BOS SMK yang menyatakan bahwa satuan pendidikan mengelola dana secara professional dengan menerapkan prinsip efisien, efektif, akuntabel, dan transparan.

Berdasarkan masalah yang telah diuraikan sebelumnya, hal tersebut menunjukkan bahwa dana dari masyarakat masih banyak berperan dalam operasional sekolah dibandingkan dengan dana dari pemerintah. Oleh karena itu, peneliti tertarik untuk melakukan penelitian dengan melakukan analisis efektivitas dana Bantuan Operasional Sekolah (BOS) di Sekolah Menengah Negeri (SMKN) se-Kota Bandung dan juga menemukan jawaban yang menjadi permasalahan besar selama ini dalam pengelolaan dana Pemerintah khususnya dana Bantuan Operasional Sekolah (BOS) baik di Kabupaten maupun Kota di Indonesia.

Tujuan dari penelitian ini adalah untuk menganalisis efektivitas dana Bantuan Operasional Sekolah (BOS) di Sekolah Menengah Kejuruan Negeri (SMKN) se-Kota Bandung.

Salah satu cara untuk menilai efektivitas dana Bantuan Operasional Sekolah (BOS) adalah dengan membandingkan antara realisasi dengan target atau aturan yang telah ditetapkan. Dana BOS dapat dikategorikan efektif apabila jumlah realisasi setiap indikator sudah hampir sama dengan target atau aturan yangtelah ditetapkan oleh pemerintah.

\section{Pertanyaan Penelitian}

Bagaimana efektivitas dana Bantuan Operasional Sekolah (BOS) di Sekolah menengah Kejuruan Negeri (SMKN) se-Kota Bandung.

\section{METODE}

Dalam penelitian ini metode yang digunakan adalah metode deskriptif. Metode deskriptif menurut Surakhmad (1990:40) merupakan suatu metode yang digunakan untuk memusatkan pada masalah-masalah aktual data yang dikumpulkan, mula-mula disusun, dijelaskan, kemudian dianalisis.

Dengan menggunakan metode deskriptif ini diharapkan dapat memberikan gambaran atau deskripsi mengenai efektivitas Dana BOS se-Kota Bandung. Dilihat dari jenis data yang digunakan, penelitian ini merupakan bentuk penelitian kuantitatif. Menurut Arikunto (2010:27) penelitian kuantitatif asalah penelitian yang banyak menggunakan angkaangka, mulai dari pengumpulan data, penafsiran data tersebut serta penampilan dari hasil ini pun diwujudkan dalam angka.

Metode analisis deskriptif kuantitatif yang mempunyai tujuan menggambarkan dan efektivitas dana BOS di SMKN se-Kota Bandung pada Tahun 2016 dengan menggunakan studi dokumentasi dari laporan Pertanggungjawaban dan BOS tahun 2016, Rencana Kegiatan Anggaran Sekolah tahun anggaran 2016, Laporan Kinerja Instansi Pemerintah Kota Bandung tahun 2016. Selain studi dokumentasi, peneliti juga melakukan wawancara dengan informan pihak yang berperan dalam mengelola dana tersebut.

Penelitian ini melibatkan satu variabel penelitian, dan untuk lebih memahami variabel atas penelitian ini, maka peneliti menggambarkan batasan-batasan atas variabel yang diteliti dengan operasionalisasi sebagai berikut :

Tabel 2. Operasionalisasi Variabel

\begin{tabular}{cll}
\hline Variabel & \multicolumn{1}{c}{ Indikator } & Skala \\
\hline Efektivitas & Untuk mengukur & Rasio \\
Dana & efektivitas dana & \\
& maka dapat diukur & \\
& melalui & \\
& perbandingan & \\
& antara realisasi & \\
& dengan rencana \\
& yang telah di \\
\hline
\end{tabular}

23 | Jurnal Pendidikan Akuntansi dan Keuangan DOI.10.17509/jpak.v6i1.15828 | http://ejournal.upi.edu/index.php/JPAK 


\begin{tabular}{lll}
\hline Variabel & \multicolumn{1}{c}{ Indikator } & Skala \\
\hline & tetapkan \\
& sebelumnya. \\
& Adapun input : \\
& Program, kegiatan \\
& tujuan, alokasi \\
& biaya, target yang \\
& diharapkan. \\
& Adapun output \\
& hasil pencapaian \\
& atau realisasi dari \\
& kegiatan yang \\
& telah dilaksanakan \\
& dengan melihat \\
& laporan. \\
\hline
\end{tabular}

Analisis efektivitas dana Bantuan Operasional Sekolah (BOS) tahun 2016.

Efektivitas $=\frac{\text { Realisasi }}{\text { rencana/aturan yang telah di tetapkan }}$

Abdul Halim (2004:164)

Untuk mengukur nilai efektivitas secara rinci digunakan kriteria berdasarkan Kepmendagri No. 690.900.327. Tahun 1996 Tentang Pedoman Penilaian dan Kinerja Keuangan yang disusun dalam tabel 3.2

\section{Tabel 4. Kriteria Efektivitas}

\begin{tabular}{cc}
\hline Persentase & Kriteria \\
\hline$>100 \%$ & Sangat Efektif \\
$90 \%-100 \%$ & Efektif \\
$80 \%-90 \%$ & Cukup Efektif \\
$60 \%-80 \%$ & Kurang Efektif \\
$<60 \%$ & Tidak Efektif \\
\hline
\end{tabular}

Sumber : Depdagri Kemendagri No. 690.900.327 tahun 1996

Sedangkan untuk data yang diperoleh diperkuat atau diverifikasi dari hasil wawancara dengan informan.

\section{Hasil Dan Pembahasan}

\section{Analisis Efektivitas Dana Bantuan Operasional Sekolah (BOS) tahun 2016}

Tabel 3. Rekapitulasi Efektivitas

\begin{tabular}{|c|c|c|c|}
\hline No. & Sekolah & Prosentase & Kriteria \\
\hline \multirow[t]{2}{*}{1.} & SMKN 4 & $86.69 \%$ & Cukup \\
\hline & BANDUNG & & Efektif \\
\hline \multirow[t]{2}{*}{2.} & SMKN 6 & $90.29 \%$ & Efektif \\
\hline & BANDUNG & & \\
\hline \multirow[t]{2}{*}{3.} & SMKN 8 & $87.63 \%$ & Cukup \\
\hline & BANDUNG & & Efektif \\
\hline \multirow[t]{2}{*}{4.} & SMKN 10 & $95.59 \%$ & Efektif \\
\hline & BANDUNG & & \\
\hline \multirow[t]{2}{*}{5.} & SMKN 11 & $92.44 \%$ & Efektif \\
\hline & BANDUNG & & \\
\hline \multirow[t]{4}{*}{6.} & SMKN 14 & $79.38 \%$ & Tidak \\
\hline & BANDUNG & & Efektif \\
\hline & Rata-Rata & $88.67 \%$ & Cukup \\
\hline & Persentase & & Efektif \\
\hline
\end{tabular}

Sumber: data diolah

Tingkat efektivitas atas dana Bantuan Operasional Sekolah (BOS) di Sekolah Menengah Kejuruan Negeri (SMKN) di kota Bandung menunjukkan bahwa efektivitas dana BOS termasuk kedalam kriteria cukup efektif karena tingkat efektivitasnya berada pada 88.67\% atau masih kurang dari kriteria efektif yang tingkatnya mencapai $90 \%$.

Hasil pengolahan data yang diperoleh dari instrument penelitian berupa wawancara dan dokumentasi memiliki tujuan untuk melihat apakah sekolah sudah efektif dalam menggunakan dana Bantuan Operasional Sekolah (BOS) atau belum di Sekolah Menengah Kejuruan (SMKN) se-kota Bandung. Berdasarkan tabel 4.25, rata-rata hasil efektivitas dana BOS di Sekolah Menengah Kejuruan Negeri (SMKN) se-kota bandung telah mencapai cukup efektif yaitu sebesar $88.67 \%$, hal tersebut dapat dilihat dalam tabel 4.25 yang menggambarkan ketercapaian indikator program yang telah mencapai $100 \%$, ketercapaian indikator kegiatan dilihat dari sisi laporan pertanggungjawaban yang telah mencapai $76.47 \%$, dan jika dilihat dari sisi realisasi ketercapaian yang telah mencapai $100 \%$, ketercapain indikator tujuan telah mencapai $88.89 \%$, ketercapaian indikator alokasi biaya $84.92 \%$, ketercapaian target dan realisasi yang diprogramkan Pemerintah Dinas Pendidikan Kota Bandung telah mencapai $100 \%$.

Indikator terendah dalam efektivitas dana BOS terdapat pada indikator kegiatan dengan persentase $76.47 \%$, indikator kegiatan tersebut telah tertuang dalam aturan yang telah ditetapkan oleh pemerintah yang mana sekolah 
diperkirakan akan menggunakan dana BOS untuk kegiatan tersebut. Berdasarkan laporan pertanggungjawban dana BOS, kegiatan yang banyak tidak dilakukan oleh sekolah adalah pada point biaya asuransi keamanan dan keselamatan serta penanggulangan bencana, hal tersebut setelah dikonfimasi kepada pihak sekolah dikarenakan hal tersebut memang jarang terjadi, dikarenakan lokasi atau letak sekolah yang tidak rawan benacana alam menjadikan kegiatan tersebut tidak dilaksanakan. Point selanjutnya yang sering tidak dilaksanakan berdasarkan aturan penggunaan dana pengembangan sekolah rujukan, setelah dikonfimasi kepada pihak sekolah ternyata untuk pengembangan sekolah rujukan memang hanya beberapa sekolah yang ditunjuk oleh pemerintah untuk menjadi sekolah rujukan. Point ketiga adalah pelaksanaan praktek kerja lapangan(PKL)/prakerin dan magang, jika dilihat dalam laporan pertanggungjawaban point PKL, 3 dari 6 sekolah yang menjadi sampel tidak menggunakan dana BOS untuk menyelenggarakan kegiatan tersebut, yaitu SMKN 4 Bandung, SMKN 8 Bandung, dan SMKN 14 Bandung. Beberapa sekolah lainnya telah melaksanakan kegiatan PKL telah menggunakan dana BOS. Sedangkan untuk point pembelian komputer dana dari dana BOS sebetulnya tidak mencukupi untuk memenuhi kebtuhan sekolah contohnya saja aturan dari dana BOS sendiri pembelian komputer dibatasi hanya 5 pes per tahun dan laptop 1 pes per tahum, sedangkan sekolah membutuhkan 20 komputer dalam satu tahun, maka dari itu dana BOS belum secara maksimal memenuhi kebutuhan sekolah.

Berdasarkan uaraian sebelumnya, hasil konfimasi ke beberapa sekolah yang menjadi sampel penelitian, menunjukkan bahwa ratarata sekolah belum efektif menggunakan dana BOS tersebut untuk kegiatan yang telah diperkirakan oleh pemerintah, sehingga dapat dilihat dari laporan pertanggungjawaban dana BOS, kegiatan yang dilaksanakan oleh sekolah dalam satu tahun masih ada beberapa yang tidak menggunakan dana BOS, baik itu dikarenakan dana BOS tidak mencukupi untuk kegiatan yang lainnya, atau pun karena memang sekolah sudah merencanakan dari awal untuk kegiatan yang seharusnya didanai oleh dana BOS diambil dari masyarakat. Sedangkan aturan yang telah dikeluakan oleh pemerintah telah berdasarkan kebutuhan yang dibutuhkan oleh sekolah selama satu tahun, maka dari itu sekolah seharusnya mempertimbangkan terlebih dahulu dana dari pemerintah sebelum menggunakan dana dari masyarakat. Tetapi pada sisi lain dana yang telah diberikan pemerintah kepada pihak sekolah tidak mencukupi untuk seluruh kegiatan sekolah, maka dari itu jika kegiatan hanya dibiayai oleh pemerintah maka kegiatan yang dilaksanakan tidak maksimal, sehingga pihak sekolah menggunakan dana dari masyarakat untuk memaksimalkan kegiatan yang akan dilaksanakan.

Selain itu, dari keenam indikator efektivitas dana Bantuan Operasional Sekolah (BOS) diketahui bahwa indikator yang mendapat persentase terendah adalah indikator alokasi biaya dengan persentase $86.09 \%$. Indikator alokasi biaya ini menggambarkan keterserapan dana yang diperoleh dengan penggunaan dananya, jika melihat dari laporan pertanggunjawaban dana Bantuan Operasional Sekolah (BOS) sampai dengan semester 3, dana BOS yang dialirkan dari pemerintah tidak sesuai dengan yang telah dikonfimasikan kepada pihak sekolah, pencairan dana BOS ini dibagi menjadi 4 kali pencairan, atau dengan kata lain dibagi menjadi 4 triwulan. Dari masing masing triwulan ada persentase tersendiri untuk pemerintah mencairkan dana kepada sekolah, yaitu dengan triwulan 1 persentase pencairan $20 \%$, triwulan $240 \%$, triwulan $320 \%$, dan triwulan 4, 20\%. Dengan melihat laporan pertanggungjawaban, maka dapat diambil kesimpulan bahwa pemerintah belum konsisten terhadap persentase pencairannya, contohnya di SMKN 6 Bandung pada laporan pertanggungjawaban tertuang dalam triwulan 1 dana yang terpakai sebesar Rp. 717.250.000,sedangkan jika melihat dari persentase untuk triwulan 1 adalah sebesar Rp. 807.800.000,(4.039.000.000x20\%), begitupun untuk triwulan 2 yang mana dalam laporan pertanggungjawaban telah terpakai sebesar Rp. 807.450.000,- sedangkan jika melihat persentase untuk triwulan 2 yaitu sebesar Rp. 1.615.600.000,-(4.039.000.000x40\%),

sehingga menyebabkan sedikit sulit untuk mengalisis jika setiap triwulan tidak berdasarkan persentase tersebut.

Indikator selanjutnya yaitu indikator tujuan telah mencapai persentase $88.87 \%$. indikator ini mempunyai 6 tujuan yang harus dicapai, tujuan pertama yaitu membantu biaya

25 | Jurnal Pendidikan Akuntansi dan Keuangan DOI.10.17509/jpak.v6i1.15828 | http://ejournal.upi.edu/index.php/JPAK 
opreasional non personalia sekolah, hal ini telah tercapai, kedua yaitu mengurangi angka putus sekolah, tujuan kedua ini telah tercapai dilihat dari hasil wawancara kebeberapa sekolah yang memang tidak banyak siswa yang dropout karena biaya. Tujuan ketiga, yaitu meningkatkan APK peserta didik, tujuan ini telah tercapai dilihat dari angka kelulusan lebih sedikit dibandingkan dengan angka siswa baru yang masuk ke setiap sekolah, maka dari itu, partisipasi masyarakat dalam menyekolahkan anaknya setiap tahun meningkat. Tujuan keempat yaitu mewujudkan keberpihakan pemerintah bagi peserta didik miskin, tujuan kelima yaitu memberikan kesempatan yang setara bagi siswa miskin untuk mendapatkan layanan pendidikan yang terjangkau, tujuan ini telah tercapai dilihat dari penurunan uang SPP dibandingkan antara sebelum adanya dana BOS dana setelah adanya dana BOS, kemudian dilihat pembebasan biaya bagi siswa yang tidak mampu dengan melampirkan SKTM untuk menunjukkan bahwa siswa tersebut tidak mampu. Tujuan keenam yaitu meningkatkan kualitas pembelajaran, tujuan ini belum maksimal dicapai dikarenakan dana yang dialirkan oleh pemerintah belum sepenuhnya mendukung kegiatan atau program yang direnacanakan oleh sekolah, hal tersebut bisa dilihat dari kesenjangan antara dana yang diberikan oleh pemerintah sebesar Rp. 1.400.000,- dan unit cost untuk SMK yang telah mencapai Rp. 6.500.000,-.

Secara khusus, dalam penelitian ini lebih menekankan kepada penggunaan alokasi biaya atau anggaran yang tepat sasaran, berdasarkan penjelasan di atas untuk indikator alokasi biaya hanya mencapai $86.09 \%$, hal tersebut menandakan cukup efektif, hal tersebut sejalan dengan pendapat Rutter et. Al (1979) dan Jhonson (1993:167) menyatakan bahwa: Keefektifan organisasi terletak pada ketersediaan anggaran yang mana ketersediaan anggaran dan penggunaan anggaran yang tepat sasaran, menggunakan prosedur perencanaan bottom up system, menggambarkan bahwa manajemen anggaran dilakukan memenuhi target dan sasaran yang ditetapkan. Strategi anggaran ini menjadi jaminan bahwa efektivitas anggaran yang difokuskan pada aktivitas pembelajaran di sekolah yang dilaksanakan sesuai dengan yang di programkan.

Berdasarkan pendapat di atas di tekankan bahwa penggunaan anggaran atau dana dijamin efektif apabila dana tersebut dilaksanakan sesuai dengan yang diprogramkan, atau dengan kata lain dana tidak dapat dikatakan efektif apabila dana tersebut digunakan tidak sesuai dengan yang telah direncanakan sebelumnya. Hal tersebut sejalan dengan pendapat Akdon et al (2015:23) menyatakan bahwa pembiayaan pendidikan merupakan aktivitas yang berkenaan dengan perolehan dana (pendapatan) yang diterima dan bagaimana penggunaan dana tersebut dipergunakan untuk membiayai seluruh program pendidikan yang telah ditetapkan. Pendapatan atau sumber dana pendidikan yang diterima sekolah diperoleh dari APBN, APBD, dan Masyarakat atau orang tua.

Dengan melihat pendapat di atas dapat dikatakan bahwa penggunaan dana haruslah dipergunakan untuk membiayai seluruh program pendidikan yang telah di tetapkan, baik itu dana yang bersumber dari pemerintah maupun dari masyarakat. Maka dari itu, untuk penggunaan dana BOS sendiri dalam penelitian ini belum sepenuhnya berkontribusi dalam mendukung program pendidikan yang telah ditetapkan sekolah, dengan kata lain program pendidikan di Sekolah Menengah Kejuruan Negeri se-kota Bandung yang berkontribusi banyak ke dalam ketercapaian program pendidikan sekolah adalah masyarakat.

Persentase rata-rata efektivitas dalam penelitian ini yaitu $88.67 \%$ lebih tinggi dibandingkan dengan penelitian yang dilakukan di SMP Negeri 1 Mojosongo oleh Ayu Alam S (2015) dengan hasil penelitian dana BOS yang digunakan tidak efektif karena nilai rata-rata persentasenya berada di $67.17 \%$. Sejalan pula dengan penelitian yang dilakukan oleh I Wayan Cenik dkk (2014) di SMA Negeri Karangasem dengan hasil penelitian menunjukkan bahwa pelaksanaan program BOS SMA tergolong cukup efektif. Penelitian yang dilakukan oleh Ayu Komang dkk di SMP Negeri 4 Seririt Kabupaten Buleleng dengan hasil penelitian ditinjau segi konteks, input, proses dan hasil adalah sangat baik.

Berdasarkan pemaparan di atas dapat dikatakan bahwa efektivitas dana BOS secara umum berdasarkan 6 (indikator) telah mencapai kriteria cukup efektif, karena seluruh target tecapai, dan terealiasi lebih dari target yang telah ditetapkan sebelumnya. Adapun berdasarkan sampel yang diambil, program/ kegiatan yang dilakukan sekolah belum secara maksimal dilaksanakan, seperti beberapa 
kegiatan dana BOS yang memang seharusnya didanai oleh dana BOS tetapi dalam laporan pertanggungajawaban dana BOS tidak dipakai untuk kegiatan tersebut, meskipun dana yang dialirkan oleh pemerintah telah terserap seluruhnya, hal tersebut dikarenakan oleh keterbatasan dana yang harus dibagi-bagi dengan kegiatan lainnya.

\section{SIMPULAN}

Berdasarkan hasil penelitian dan pembahasan pada bab sebelumnya, mengenai dana yang berikan pemerintah untuk sekolah yang disebut dengan dana Bantuan Operasional Sekolah (BOS), maka dapat diperoleh kesimpulan bahwa:

Efektivitas dana Bantuan Operasional Sekolah (BOS) di Sekolah Menengah Kejuruan Negeri (SMKN) se-kota Bandung telah cukup efektif dilaksanakan dengan melihat persentase sebesar $88.67 \%$. Hal ini menunjukkan bahwa penggunaan dana Bantuan Operasional Sekolah (BOS) belum sepenuhnya berkontribusi dalam rangka mendukung kegiatan sekolah, sehingga masih banyak peran masyarakat dalam mendukung kegiatan sekolah.

\section{SARAN}

Berdasarkan kesimpulan yang telah dijelaskan diatas , untuk masukan sebagai bahan pertimbangan bagi Pemerintah dan satuan Pendidikan Menengah dalam rangka mengoptimalkan kontribusi pemerintah dalam mendukung pendidikan menengah kejuruan, maka saran bagi Pemerintah yaitu Dana Bantuan Operasional Sekolah (BOS) merupakan dana yang memberikan harapan keringanan bagi masyarakat dalam mengenyam bangku sekolah. Akan tetapi, dana BOS sendiri belum ada ukuran berapa persen dalam meringankan beban masyarakat, dikarenakan biaya rata-rata per siswa mencapai cukup besar dikeluarkan oleh para orang tua. Selain itu, konsistensi dalam penyaluran dana berdasarkan persentase per triwulan belum konsisten dilaksanakan. Maka dari itu, pemerintah diharapkan dapat memberikan gambaran yang seperti apa yang meringakan beban masyarakat itu, jika masyarakat masih berperan banyak dalam memenuhi kebutuhan di sekolah atau kegaitan sekolah.

Saran bagi sekolah yaitu dana BOS yang dikelola oleh pihak sekolah haruslah berdasarkan prinsip pengelolaan dana yang tertuang dalam Petunjuk Teknis Penggunaan dan Pertanggung Jawaban Dana Operasional Sekolah (BOS), yaitu efisien, efektif, transparan dan akuntabel. Efisien berarti dana BOS haruslah dipakai dengan cermat, maksud cermat disini adalah haruslah pintar memilih apa yang seharusnya dibelanjakan dan berapa yang harus dikeluarkan untuk mencapai hasil yang sama tetapi dengan penegeluaran yang seminimal mungkin. Dengan penegeluaran yang seminimal mungkin diharapkan dapat mencapai prinsip efektif yaitu kegiatan dilaksanakan sesuai dengan rencana atau aturan yang telah di tetapkan. Kemudian transparan berarti sekolah diharapkan terbuka dalam pengelolaan keuangannya, keterbukaan itu maksudnya publik atau masyarakat dapat mengetahui pengelolaan keuangan sekolah tetapi sesuai dengan porsi yang memang haruslah di publikasikan untuk masyarakat umum. Sedangkan untuk akuntabel, sekolah diharapkan dapat mengelola keuangan atau dalam hal ini adalah Dana BOS secara akuntabel, atau dengan kata lain pencatatannya tepat sesuai dengan bukti transaksi, sehingga pembuatan laporan pertanggung jawaban pun tidak akan terlambat dilaporkan. Dengan demikian, harapan peneliti kepada pihak sekolah dalam mencapai efektivitas dana BOS diharapakan manajemen sekolah dalam mengelola keuangan dapat ditingkatkan, apabila perlu haruslah ada yang memang spesifik menangani keuangan sekolah khususnya BOS.

Saran bagi peneliti selanjutnya diharapkan dapat menyempurakan penelitian yang telah dilakukah. Diharapkan penelitian selanjutnya dapat dilakukan dengan cakupan objek yang lebih luas dan mengembangkan variabel lain yang berkaitan dengan prinsip pengelolaan dana dari pemerintah, seperti Efisiensi, Transparansi, dan Akuntabel. Karena dalam penelitian ini hanya membahas mengenai variabel efektivitas saja.

\section{DAFTAR PUSTAKA}

Akdon. Kurniady, D.A. Darmawan, D, 2015. Manajemen Pembiayaan Pendidikan. Bandung: PT Remaja Rosdakarya.

Arikunto, S., 2010. Prosedur Penelitian Suatu Pendekatan Praktik. Jakarta: PT. Rineka Cipta.

Halim, A. (2004). Manajemen Keuangan Daerah. Yogyakarta: UPP AMP YKPN. 
Mulyono, 2010. Konsep Pembiayaan Pendidikan. Yogyakarta: Ar-Ruzz Media.

Rutter, M. M. B. M. P. \&. O. J., 1979. Fifteen Thousand Hours: Secondary Schools and Their Effect on Children. London: Prentice Hall. Inc.

Fitria, H., 2015. Efektivitas Pengelolaan Program Bantuan Operasional Sekolah (BOS) (Studi Pada SMK PGRI PANDAAN). E-Journal UNESA, Volume 3, p. 2.

Ayu Komang Ratna Dewi, I Made Yudana, Anak Agung Gede Agung, 2015. Efektivitas Program Bantuan Operasional Sekolah (BOS) Pada SMO Negeri 4 Seririt Kabupaten Buleleng. eJournal Program Pascasarjana Universitas Pendidikan Ganesha, Volume 6, p. 1.

I Wayan Cenik, A.A Gede Agung, I Made Yudana, 2014. Efektivitas Program BOS SMA di SMA Negeri Kabupaten Karangasem Dalam Rangka Mendukung Pendidikan Menengah Universal. eJournal Pascasarjana Universitas Pendidikan Ganesha.

Setyorini, A. A., 2015. Efektivitas Biaya Pendidikan (BOS) SMP Negero 1 Mojosongo Tahun Ajaran 2014/2015. SKRIPSI.

Setyoko, A. Tunas, B. Sunaryo, W., 2016. Evaluation of School Operational Assistance by using CIPP Model in
Indonesia Private Islamic Elementary School. International Journal of Managerial Studies and Research (IJMSR), 4(3), pp. 44-49.

Sumarni, 2014. Efektivitas Dana Bos Terhadap Peningkatan Mutu Di Madrasah. EDUKASI, Volume 12.

Setyorini, A. A., 2015. Efektivitas Biaya Pendidikan (BOS) SMP Negeri 1 Mojongoso Tahun Ajaran 2014/2015. Yogyakarta: Universitas Negeri Yogyakarta.

Kepmendagri No. 690.900.327 tahun 1994 tentang Pedoman Penilaian dan Kinerja Keunagan

PERMENDIKBUD No 16 Tahun 2016 Tentang Perubahan Atas Peraturan Menteri Pendidikan Dan Kebudayaan Nomor 80 Tahun 2015 Tentang Petunjuk Teknis Penggunaan Dan Pertanggung Jawaban Keuangan Dana Bantuan Oprasional Sekolah

Peraturan Pemerintah No. 47 Tahun 2008 Tentang Wajib Belajar

Peraturan Pemerintah No. 48 Tahun 2008 Tentang Pendanaan Pendidikan

Undang-Undang Dasar Negara Republik Indonesia Tahun 1945

Undang-Undang No. 17 tahun 2003 tentang Keuangan Negara

Undang-Undang No.20 Tahun 2003 Tentang Standar Nasional Pendidikan 